\title{
In Search for Strength: A Regime (in) Security Facing Mass Protests in Ethiopia, 2015 to 2018
}

\author{
Bekalu Wachiso Gichamo \\ Department of Civics and Ethical Studies, Wolkite University, Wolkite City, Ethiopia
}

Email address:

bwachiso@gmail.com

To cite this article:

Bekalu Wachiso Gichamo. In Search for Strength: A Regime (in) Security Facing Mass Protests in Ethiopia, 2015 to 2018. International and Public Affairs. Vol. 4, No. 2, 2020, pp. 20-27. doi: 10.11648/j.ipa.20200402.11

Received: January 21, 2020; Accepted: March 6, 2020; Published: August 25, 2020

\begin{abstract}
Drawing from extensive, comparative empirical data and relevant literature, this paper attempts to answer the question as to how and to what extent does pursuit of regime security explain the recent popular protests in Ethiopia. The insecurity of the regime is manifested in a state weakness, where the regime tries to gain strength but meets resistance from society; the resistance makes the regime adapt more coercive strategies for consolidation of state power which generates further resistance. This paper argues that human insecurity in Ethiopia has been mainly the result of the authoritarian nature of the state and the ruling party's unprecedented pursuit of regime security. The author found out that the regime's resilience seemed rooted in the strategies it has utilized in order to stay in power - namely, the quite disproportional deployment of coercive force to quash popular demand for reform; manipulations of the democratization process, and co-opting democratic institutions of the state. For the author, to address the root causes of human security problematic is essential for ensuring citizens' prosperity and security thereby building a secure Ethiopian state.
\end{abstract}

Keywords: Regime Security, Ethiopia, State Weakness, Human Insecurity, Mass Protests

\section{Introduction}

For weak states including African states, security does not simply refer to external orientations or military capacities, but implies a wide range of preconditions vital for the existence of the state, which have already been realized in developed countries. Because weak states lack internal socio-political cohesion, the majority of the threats to their security originate from within their boundaries rather than outside them [1]. Because most of the developing states are weak states, they face legitimacy crisis than the developed Western counterparts. Their state structures lack legitimacy and cohesiveness. Consequently, as Jackson [1] points out, the combination of state weakness and internal threats creates a security challenge unique to weak states. It is distinctive because it arises from meeting internal threats to the regime in power, rather than external threats to the existence of the nation state.

As the argument goes, the prevalence of human insecurity in Africa, in particular, presents useful leads towards the consideration of the challenges with orthodox security as well as an appreciation of the essence of human security. In this respect, as of Kassahun [2] contends that in the Horn of Africa, the perennial practice of lending primacy to regime survival and elite privilege to the detriment and neglect of human security preoccupy.

The Ethiopian state, Kassahun [2] asserted, when compared to the past, particularly the era of military dictatorship, a relatively significant betterment in socio-economic and political terms poses as the hallmark of the Ethiopian body politic of the post-1991 years. Suffice to cite the legal recognition accorded to such matters like respect for democratic, human rights, and civil liberties [2].

Nevertheless, many scholars and observers concluded that there is a huge gap between EPRDF's promises of democratization and its actual performance on the ground. In similar vein, others are keen to argue that Ethiopia's security landscape is largely shaped by regime security often at the expense of human security [3-6]. Empirical data shows that beginning in November 2015, large and unprecedented wave of popular protests has erupted in Ethiopia. The protests first swept across the Oromia region, reflecting widespread discontent with the incumbent government's plan to expand the capital Addis Ababa into Oromia, which the protesters 
feared it would marginalize and deprive farmers from their ancestral lands. With the mounting of public resentment, the government suspended the plan in January 2016, yet, the protesters were not satisfied by this decision and the unrest has continued. It has been witnessed that although protests remained largely peaceful, the later increasing lethality and indiscriminate nature of state repression to control the protests may have contributed to the escalation of the tensions.

This paper argues that the emergence of the dramatic and rapid upsurge of the popular protest in the country is a paradox given EPRDF claimed to have won-together with allied parties-every seat in the Parliament in the 2015 national elections. In fact, it can be said that, while unrest and violence had been common fixtures of Ethiopian political life over the previous twenty-five years of EPRDF rule, the simultaneous Oromo and Amhara protests may have represented a unique crisis of legitimacy and largely showed the failure of the government's divide-and-rule strategy. This failure was particularly apparent when Amhara protestors began to declare solidarity with the Oromo, their historic adversaries, using such rallying cries as: "we are all Oromos," "I am not Oromo but I stand with my Oromo brothers," and "the blood that flows in Oromia is our blood too." As it had done with previous protest movements, the EPRDF branded the Amhara protests as the work of terrorists and anti-peace forces and authorized the military and security forces to use all means necessary to bring them to an end, which did not work as tactics, however.

Against the above backdrops, the study examines and contextualizes the recently unfolding political crisis in the country by employing a human security approach. To this end, the study will attempt to demonstrate as to how the human security problems which for this paper is about the political, economic and social securities of individuals or as a condition where citizens are secure from poor governance and political violence, have contributed to the public frustration. There is a paucity of literature to discuss the issues thereof and this study is an attempt to fill this void.

\section{Conceptual Frameworks}

\subsection{Regime Security}

Regime security has been defined as 'a condition where the governing elites are secure from the threat of forced removal from office and can generally rule without major challenges to their authority' [1]. Holm [7] underscores that regime and state security are quite indistinguishable as one cannot speak of the one without speaking about the other or they are difficult to disentangle them as two sides in the same coin.

State institutions like bureaucracies, militaries, parties, and domestic security services are often creations of the incumbent political regimes to help them prolong their tenure in power. Gudeta [3] observed that regimes like Ethiopia and Sudan have a narrow base of support from the wider public. Hence, it is worthwhile to note that state institutions serve the narrow interest of the ruling circle because of which the fault line between the regime and state security remains hazy. Medhane [8] posited, 'state security in the horn of Africa amounts to little more than regime security', and if the concept of state is disconnected from the concept of regime, the latter will try to 'securitize' both state and itself in order to survive as incarnation of the former [7]. Therefore, any challenge to the regime is counted as a challenge to the state and thereby to the regime [7].

Thus, one can infer that state security in the context of the developing states could be taken as 'a condition where the institutions, processes and structures of the state are able to continue functioning without the threat of collapse or significant opposition, despite threats to the current regime or changes to the makeup of the ruling elite' [1]. When the ruling elites in the Third World face internal threats to their survival, they may use foreign policy in addition to domestic tools to enhance their political security $[9,10]$ by soliciting support from powerful global actors. For instance, it can be observed from the post 1991 Ethiopian experiment that '...one basic feature of the ruling party's (Ethiopian People Revolutionary Democratic Front, EPRDF) policy is still contested to be '...a mismatch between what is official and textual on one hand, and the practice and the real thinking of the regime on the other' [6]. In the same vein, the regime's national security policy and strategy document, attests to the fact that, at the formal level, it (the regime) adamantly declared that the alpha and omega of its national security policy and strategy is to protect Ethiopia's national interest and to ensure its (state's) survival [4].

By way of conceptual clarity, regime security for the purpose of this study is mainly associated with the ruling elite's security or it can be an ability of the ruling regime to secure its power through suppression and political manipulation.

\subsection{Human Security}

The concept of human security was first elucidated in the 1994 UNDP Report as part of the holistic paradigm of human development [3]. Thus, the official launching of the concept and its cognate, human development, in the global fore is credited to the UNDP Human development report [3]. The report gave concrete expression to and was later used to popularize, the notion of human security [11]. The UNDP Human development report argued for a new concept of security that equated security with people, rather than territories or states [12]. It seeks to shift the meaning of security away from its traditionally military-oriented and state-centered focus. Accordingly, the report envisages "human security in the sense that the individual is at the receiving end of all security concerns" [13]. It characterized human security as 'freedom from fear and freedom from want', which can be said to have two main aspects. First, it means safety from such chronic threats as hunger, disease, and repression. Second, it means protection from sudden and harmful disruption in the pattern of life. The report defined human security by listing seven aspects of it: economic security, food security, health security, environmental security, personal security, community security, and political security. 
These components make the definition of human security allencompassing. The UNDP report on human security has four core elements. It is people-centered, multi-dimensional, interconnected, and universal [3].

Based on the UNDP definition of human security, currently, there are broad and narrow approaches to conceptualize the term human security [14]. The narrow conception of human security is focusing on 'freedom from fear' and factors that perpetuate violence. In this approach, human security emphasizes the protection of individuals from direct threats to their safety and physical integrity, including the actions of the state against its citizens [15], and the key strategies for strengthening human security are identified as 'strengthening legal norms and building the capacity to enforce them' [16]. The broad definition of human security, on the other hand, entails three ideas i.e. 'freedom from want', 'freedom from fear' and 'freedom from indignity'.

Human security puts people first, emphasizing that human rights are central to state security. Human security complements human rights law by drawing attention to international humanitarian law in the context of armed conflict. Nonetheless, despite their complementarity and interdependence, the two are not always cordial [4]. According to Alemayehu [4], the state plays a major role in guaranteeing human security, but it may also pose an existential threat to the citizenry's security. Put simply, as Salih [17] aptly put it, Human security is about "protecting and empowering citizens to obtain vital freedoms from want, fear and hunger, as well as the freedom to take action on one's own behalf, including, among other things, creating the building blocks for human flourishing, peace with dignity and a secure livelihood" [17].

By way of conceptual clarity, human security for this study is about the political, economic and social securities of individuals. Alternatively, it can be understood as a condition where citizens are secure from poor governance and political violence.

\section{Materials and Methods}

Even though the experience of popular protests has not been uncommon in the rich history of Ethiopia, the researcher considers only the period since 2015 by way of analytical purpose. As such, the study mainly investigates to what extent the absence or deficit of human security fits defining the protests since 2015 . The attempt here is thus, neither to examine the intricate relationship (horizontal and vertical possibly) between the various actors in the protest, nor to discuss human insecurity and other issues like, civil war, human insecurity and ethnic conflict; human insecurity and regime types and the like. To achieve this goal, the study adopts a qualitative research approach which helped the researcher to explore attitudes, experiences and an in-depth opinion from participants and emphasis on the interpretation of observations in accordance with subjects' own understandings. This study used a descriptive case study to answer the first and the second questions i.e. what is the nature of human security in post-1991 Ethiopia in general and since 2015 in particular? And what is the relation between regime security and human security in the Ethiopian context? On the other hand, to answer the third research question, this study deployed an explanatory study strategy built in the theoretical framework presented and conducted the dialogue of ideas and evidence.

The technique the author used in examining the empirical information regarding the actual operation of regime security and human security in Ethiopia was divided into two: analysis of documents, and qualitative interviews with key informants. Accordingly, interviews were conducted until data saturation. As a result, the research teams (of which the author is team leader and project principal investigator) conduct a key informant qualitative interviews with forty-eight (48) purposely selected individuals including government officials, intellectuals and experts, party leaders, community leaders, and some residents in the research sites.

Table 1. List of interviewees.

\begin{tabular}{llll}
\hline No & Organization/association & $\begin{array}{l}\text { Number of } \\
\text { interviewees }\end{array}$ & Status \\
\hline 1 & Government communication affairs & 2 & Focal Persons \\
2 & Institute of Ethiopian Studies/AAU & 4 & Directors, experts, professionals \\
3 & Centre for Human Rights/AAU & 3 & Directors, experts, professionals \\
4 & Department of Political Science \& International Relations & 4 & experts, professionals \\
5 & Peace \& Security Studies Institute/AAU & 6 & Directors, Experts, Researchers, Professionals \\
6 & Opposition party Office/Addis Ababa & 4 & Party leaders, members \\
7 & Informal Youth Associations & 25 & Community Elders, coordinators and some Protesters \\
\hline
\end{tabular}

Besides, two focus group discussions have also been conducted by way of data triangulation. Regarding the theoretical framework, the study deployed literature mainly in the field of regime security, state weakness, and human security in Africa at large and in Ethiopia in particular. The selection of theories and conceptual frameworks was based on their contribution in explaining and interpreting the reality as well as their ability in establishing a framework for observing and conceptualizing the empirical research.

In general, the motivation behind the research approach in this study was to extend the analytical instrumentality of prioritizing regime security at the expense of human security based on how regimes in weak states deal with domestic popular dissents and the overall implication of these for the deteriorating human security conditions in these states.

Regarding the scope of the study, as shown in the following figure [figure 1], this study has been delimited geographically in the Amhara and Oromia regional states, the two large regional states in Ethiopia, and where the massive popular protests took place. 


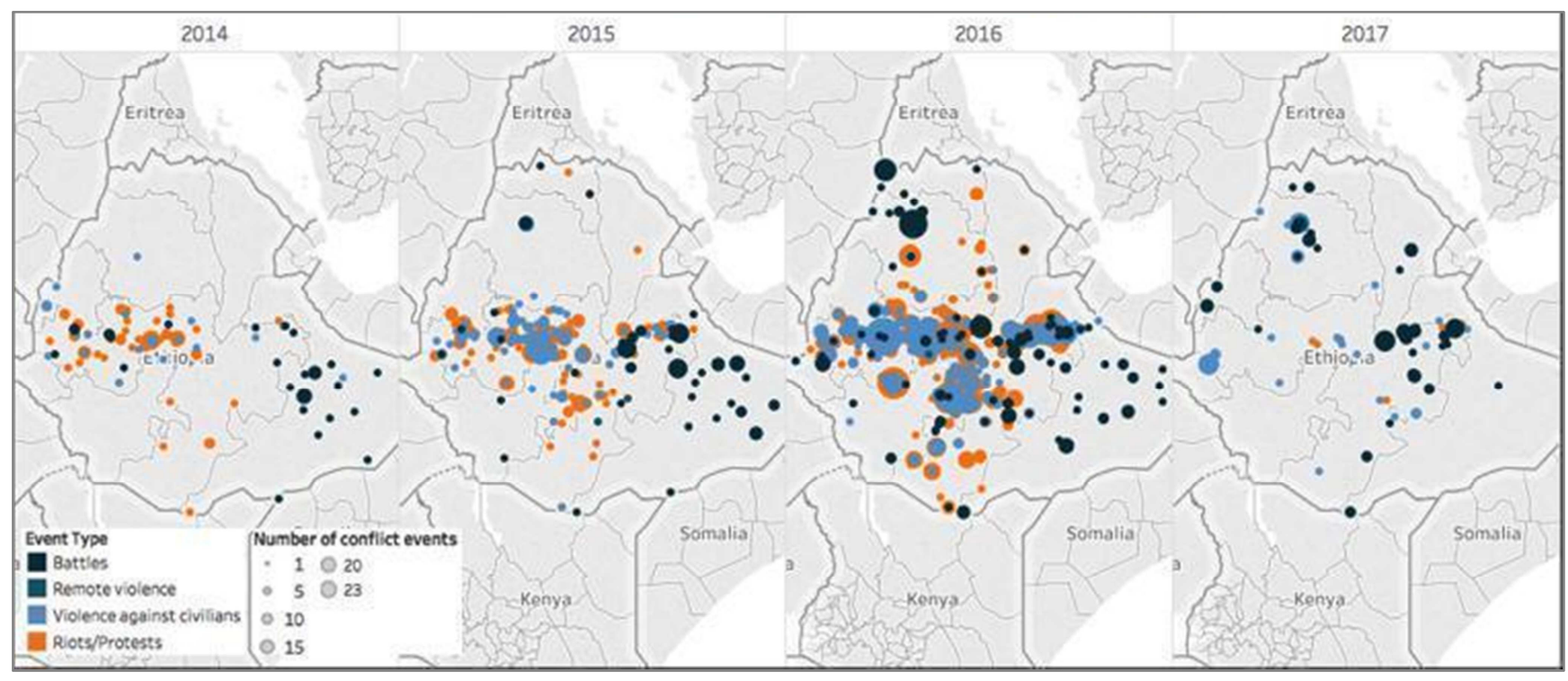

Source: adapted by the author from ACLED Conflict trend report [18].

Figure 1. The Spatial and temporal coverage of the popular protests in Ethiopia.

\section{Results and Discussions}

\subsection{Regime Security in Post 1991 Ethiopia}

The political culture in Ethiopia hitherto seems not an exception but a shared rule with countries in the Horn region since repression is the ultimo ratio of state power, and all regimes have certain properties that lend themselves to the development of draconian practices. Protests, particularly by Oromos, seemed to have long been viewed by the government through the prism of security. As the author will demonstrate in this Article, many of the measures that the Ethiopian government took to quash the protests appear to represent long-standing government policies and practices. In other terms, the author will be demonstrating how Ethiopia's security landscape is largely shaped by regime security often at the expense/neglect of human security [2-6] or while paying insufficient attention to other dimensions, such as human security, that are equally important.

Despite the EPRDF's failure to keep its promises, it has managed to solidify the power and survival of both of its own and that of the regime. Varieties of factors explain as to why the EPRDF regime has managed to stay in power thus far. For many, coercion has been identified as one of the most important strategies of state and regime survival in Ethiopia. The Ethiopian state is among those that is unable to establish legitimacy, and therefore, largely survives through using apparatus of coercion. EPRDF loyalists lead the security organs of the state, the Ethiopian National Defense Forces, the federal police, the rapid response forces regional police and local militia. The role of the police appears to be as crucial for the survival of the EPRDF, quite reminiscent of the previous regimes [19]. Yet, coercion alone does not seem to be sufficient to explain as to why the regime managed to stay in power for long.
Although EPRDF has not been averse in the use of coercion to silence opponents, it also uses the mechanisms of consent building as means of staying on power. The regime often manipulates democratization process for instance. Some emphasize the role of the regime's ideology, revolutionary democracy. For example, Bach [20] contends, revolutionary democracy as defined by EPRDF after the 2005 elections provides an intellectual justification and/or program for the merger of the party with the state, government and the entrepreneurial class. Although 'revolutionary democracy' has not been properly defined, the incumbent government defines it as a rival to liberal democracy. As Merera [21] noted, the government officially presents revolutionary democracy as....an anti-thesis of liberal democracy, its modus operandi based on the Leninist principle of "democratic centralism' 'This has brought about a fusion of party and state that negates the separation of powers and undermines the checks and balances that mediate state powers elsewhere in the democratic world.

According to Markakis [22], revolutionary democracy is founded on an 'unshakable conviction carried over from a Marxist upbringing that there is only one 'correct line' and only one genuine revolutionary movement. Abbink [23] argues that the governing ideology of the ruling party is often in contradiction' with the Constitution. However, the regime has also built a party structure that retains a degree of control to the extent that in practice it would be difficult to use these democratic institutions effectively to challenge the power of the ruling party [24].

Similarly, the main reason behind the sudden promotion of the developmental state discourse appears to be the need to provide a new legitimacy for a regime that failed to translate its promises of democracy, peace and development into practice. In Ethiopia, where the peasantry constitutes $85 \%$ of the total population, behind developmental state ideology of 
the regime intention seems to control the peasantry but not to empower [6]. For this purpose, the controlling mechanism was said to be maintained through the rural kebeles [6].

On the other hand, what usually accompanying elections have been allegations and counter- allegations on the one hand and political crisis subsequent to election results, on the other hand [6]. This has been the decisive truck for ensuring regime security and below the surface it has built [on] a party structure that keeps tight control at all levels and makes sure that no one uses these democratic institutions efficiently to challenge its power [5].

Still another instrument of the regime is the legislature/parliaments by whose uncritical support and rubber stamp effect the regime got most of its decisions and policies legitimized. Regardless of the official and formal facades that portray the Ethiopian Legislature as an institution that came into being because of liberal reforms and attendant arrangements, one can justifiably argue that its existence and mode of operation is a function of power relations closely associated with the workings of party politics and electoral systems [25]. In the circumstances, parliament is an organ of government rather than an instrument of governance influencing and changing the course of public policy [25].

Co-option is another extremely important in order for the regime to be able to control other state institutions and coopt people into its power nexus. Merara [26] said, "The EPRDF leaders, keen on the consolidation of their hard-won victory, made sure to selectively invite weak parties most of which were created overnight, and selectively excluded the actual or potential real power contenders from the process". Thus, the party's centralized hold on power seemed to depend to a large extent on the interlinked dynamics of generating legitimacy through output in terms of social service delivery and economic growth, using economic and security incentives to maintain loyalty to the party, and limiting meaningful political competition, which results in short term politics $[9,8]$.

\subsection{Pursuit of Regime Security at the Expense of Human Security: Evidence from the Popular Protests}

In 2015, Ethiopia experienced its first protests against the government, mainly affecting the Oromia region. The reasons behind the protests were multiple: a combination of socio-economic, ethnic, and land issues that had seriously hampered the fragile peace efforts in Ethiopia for decades. It can be said that the protests have been largely concentrated in Oromia and Amhara regional states. The protests seemed to suggest that the government's authoritarianism has not changed significantly. In other words, as of a number of scholarly accounts, the transition process towards democratization has failed, and Ethiopian politics can be characterized as being based on clientelism, nepotism, ethnic favoritism, and the use of repressive methods [22, 20].

However, as of a former government communication affairs minister [interview result], the understanding on the part of the government about the peoples' grievances mainly has been about lack of good governance. Other interview results also confirmed that priority of the government is primarily on addressing governance issues because people are not getting the kind of services they deserve. The government time and again claimed it achieved significant economic progresses over the last two and half decades but distribution of wealth still has a long way to go before millions and millions of youth in this country. For instance, the developmental state politico-economic model by the government has often been criticized as: there have been visible changes in the primarily urban areas, on the one hand, coupled with the stagnation in the quality of social services, including salaries, on the other. The existing mixture of social inequality, religious tension, ethnic rivalry, and regional discrepancies frequently leads to a deeper level of social frustration, and this phenomenon has been observed particularly among young people, who constitute the most numerous proportions of Ethiopia's population of over 95 million. This seemed to make Zahorik and others to conclude, the "developmental state" in Ethiopia after 1991 can only be described as paradoxical [27].

Similarly, critics also disputed that the government should not downplay the popular discontent primarily as a governance predicament. A respondent posited: "we are not at a time when it is possible to deceive the people by raising the issue of good governance, the corrupt practices, and etcetera. The government should no longer cheat on the people. This is long standing grievance against Human insecurity and Human Rights violations in all aspects yet unresolved. Thus, it is too little too late to talk about good governance or malpractices. The people are just asking for a change in system or regime" [interview result].

As FGD discussants put "successive regimes for the past several decades showed few signs of being able to solve the morass of problems, which many believe the government itself caused. Popular grievances against a background of political insecurity have also been apparent" [FGD discussants]. The protests occurred against such a background of nearly non-existent political space in parliament, where the ruling coalition has hundred percent of seats; there are restrictions on civil society and independent media, and those who do not actively support the government often face harassment and arbitrary detention [27, 28].

Besides, it has been said that there was a gap between EPRDF's promises of democratization and its actual performance. This was particularly evident in the 2005 election when "EPRDF lost a considerable number of parliamentary seats but was determined to retain power and supreme command" [22, 20, 27]. It has also been said that the 2005 elections and the aftermath may have greatly affected human security $[22,20,27]$.

In spite of the fact that human and democratic rights feature prominently among the factors that enhance human security [5], the representation of popular dissent in the political domain has been dwindling from time to time and elections have not been fair 'for the most part' but mere political rituals undertaken at periodic intervals [26-28]. 
Though it has been said that the democratic institutions have long been started to be influential when it comes to the protection and implementation of human rights in Ethiopia, some individuals disputed such statements by saying the major democratic institutions, not precluding the Ethiopian Human Rights Commission and the Ombudsman, are not ascertaining their independence and impartiality from the executive organ. For example, a respondent explained his remarks saying: the performance of what we call [democratic institutions] in Ethiopia has never been comparable to their age [interview result]. A human rights expert strengthens this point positing: "people still question the independence and impartiality of such institutions in Ethiopia and they are also criticized for focusing on minor issues while neglecting their major tasks. For instance, they are accused of shying away from major national issues, which have serious implications on the protection of human rights. Consequently, they contribute less for their check and balance role" [interview result].

Besides, violations of the rights to freedom of expression and association and freedom of the media have been linked to human insecurity. Gudeta [3] is among the scholars who are of the position that the political regime has been frequently resorted to crackdowns on the country's private media. Instead of living up to its promises, the ruling regime in Ethiopia seemed to have been busy in promulgating series of legislations constraining freedoms that are instrumental for the construction of a democratic system. The most infamous ones among such legislations includes the freedom of Mass Media and Access to Information Proclamation (Proclamation No. 590/2008), the Anti-terrorism Proclamation (Proclamation No. 652/2009), and the Charities and Societies Proclamation (Proclamation No. 621.2009) [3].

For instance, a recent example of what the rhetoric regarding the anti-terrorism law is said to be the government's labeling of the protesters in Oromia who demonstrated against its intended expansion of the city limits of Addis Ababa as "linked to terror groups" or "anti-peace groups" working "in close collaboration with foreign elements" [30]. A government official seems to strengthen this in saying, "We know the protests are based on false claims. The protesters are demonized, motivated by 'the conspiracies of destructive forces'... 'of evil forces', of 'anti-peace elements', including opposition parties which are, for good measure, 'the proxies of the Eritrean regime', and are now 'organizing armed gangs"” [interview result].

Yet, there remained adamant criticisms against the government for being intolerant to criticism and see citizens utilize their freedom of expression, assembly and organization to challenge it [3]. As a strategy of categorically rejecting criticism, the regime has been said to seriously undercut these rights of individuals [31].

The other issue behind the popular discontent in Ethiopia may have been linked to the grievance over economic inequality. In regards of this, the author found out that most of the economic issues and conflicts in Ethiopia are largely linked to land. From a legal standpoint, the land in Ethiopia is owned by the State. The Ethiopian government claims the land it leased to foreign investors is currently not being used or sporadically being used by the local population [see 32-34]. The government hopes that investors will bring modern technologies, which will make agriculture more efficient. The Government keeps on asserting that the land policy is a form of social protection because it protects farmers against distress sales, land concentration in the hands of the wealthy and subsequent exploitation of the poor farmers. In reality, the reverse seems to be the case. For instance, tenure insecurity [because] of demographic pressure or eviction by the state has locked the smallholder agriculture in downward spiral of low productivity, and income insecurity has become more prevalent due to dramatic rise of rent seeking among the political elites [32-34].

A peace and security expert opined, "people, who are able to, although with some difficulty, provide for their own livelihood are now forced to become low wage laborers. People, instead of working on the land for themselves, they will have to work for a boss" [interview result]. In the last few years only, the government has been evicting farmers at will to undertake urban expansion and large-scale private commercial agriculture, provoking some to name it “development by dispossession" [34].

For one villager in one of our research sites in Oromia, the issue of land grab is associated with life. He said, "for me it's not a land grab. It is life grabs. It is grabbing the lives and the future of we, the people. We are not people who have grown up on food that is been brought by income from the office. We are people who survive on the land.... we are agriculturalists" [interview result]. Accordingly, and by all reviews so far, the recent popular protests (in the Oromia regional state in particular) seemed to be a social movement in the making in opposition to such massive eviction of farmers from their land by the state in the name of what the defunct regime often dubbed development and urban expansion.

In fact, it can be argued that the Ethiopian People's Revolutionary and Democratic Front [EPRDF] regime has done much to realize economic reforms in Ethiopia. To revitalize the economy as a way of ensuring economic security for Ethiopians, a number of structures have been put in place. Yet, critiques dispute, the distribution of benefits has been quite inequitable which produce regional inequality as some regions have been allegedly claimed that they have been excluded from the overall economic improvements thereof.

Similarly, despite liberalization and economic growth in the formal sector, the problems of food insecurity, public health, unemployment, urban poverty, disrespect of human rights, and ethnic tensions were not resolved, and public dissatisfaction mounted [29]. Furthermore, while state-led growth averaged an impressive $10-11 \%$ per year over the period 2003-13, Ethiopia's ranking on the Human Development Index has not moved by much, which is partly a reflection of its population growth and the difficulty of translating macro-growth into micro-gains [35, 36]. 
In sum, the authoritarian security paradigm is prevented by its narrowness and state centralism from identifying the deeper, underlying threats and causes of instability, which stem from the absence of human security.

\section{Conclusion}

Since November 2015, large and unprecedented wave of popular protests have erupted in Ethiopia. In the last three years (as of the time of writing), the country has seen not merely the abandonment of (except window-dressing attachment to) the values of human security, but also the adoption of measures that do far more harm than good in the search for consensual political and economic development and social cohesion in the years ahead. As this study found out, the regime's resilience seemed rooted in the strategies it has utilized in order to stay in power - namely, the quite disproportional deployment of coercive force to quash popular demand for reform; manipulations of the democratization process, and co-opting democratic institutions of the state. In other words, the regime's responses to the popular demands for the most part appear to be brutal crackdowns while maintaining its own survival, which in turn does not seem a viable option for long-term governance. By stripping away at broader approaches to security that could have assisted regimes to construct more inclusive politics, that can weather the eventual transition to post-redistributive economy, the measures taken by the regime largely attested to the prioritization of regime security, which led to deteriorating condition of Human security. This have narrowed the socio-political base of popular support and undermined the strategies of economic diversification that meant to smooth the path to sustainability.

This study has also identified that the recent protests had come out largely because of growing popular frustrations against the deteriorating conditions of human security since 1991, which is mainly attributed to the negative role that the 'undemocratic' regime and the authoritarian nature of the state in Ethiopia played in pursuit of regime survival while neglecting citizens' human security concerns. In other words, these popular protests were in pursuit of a new contract (social and political, if not a change of regime based on human rights rather than political oppression, human security in lieu of prolonged fear, and human dignity in lieu of lingering humiliation by the ruling regime to date. In Ethiopia, despite the rhetoric, the incumbent regime has been using considerable amount of the state resources and power structures to achieve its own security to the detriment of peoples' human security. This has indeed not only put the country in a state of political and development impasse because of intrastate conflict, but also erodes the political domain and curtailment of the political and democratic rights of the citizens in the country.

Today the chronicles of those happenings still signalled as caveats for the new leadership to stay away from the misuse of popular authority. For this researcher to address the root causes of human security problematic is essential for ensuring citizens' prosperity and security thereby building a secure Ethiopian state.

\section{References}

[1] Jackson, R. (2010). "Regime Security" in A. Collins (ed.), Contemporary Security Studies. Oxford: Oxford University Press, pp. 186-200.

[2] Kassahun, B. (2013). "Conflicts in the Horn of Africa and Implications for Regional security", in Redie Bereketeab (ed.), The Horn of Africa intra-State and inter-State conflicts and Security, The Nordic Africa Institute Pluto Press. pp. 71-95.

[3] Gudeta, K. (2014). "A pair of opposite security issues in the horn of Africa: human security versus regime security in Ethiopia", International Journal of Development Research Vol. 4, Issue, 2, pp. 252-261 February 2014.

[4] Alemayehu, F. (2009b). "Ethiopia's Foreign Affairs and National Security Policy: A Critique", Reporter, November 21.

[5] Pausewang, S. (2002a). "Ethiopia: Crisis of State, Good Governance and the Reform of the Security Sector", in T. Debiel, \& A.

[6] Melakou, T. (2007). Structural and Conjectural Constraints on the Emergence of a Civil Society/Democracy in Ethiopia, 1991-2005. PhD Thesis, University of South Africa.

[7] Holm (2003). "Violence in Algeria: A Question of Securitization of State-Regime, Nation and Islam Alternatives", Turkish Journal of International Relations, Vol. 2, No. 2.

[8] Medhane T. (2004). Turning conflicts to cooperation Towards an energy - led Integration in the horn of Africa. Friedrich Ebert-Stiftung.

[9] Clapham, C. (1996). Africa and the International System: The Politics of state Survival. Cambridge: Cambridge University Press.

[10] Yong (2000). "State Security and Regime Security: President Syngman Rhee and the Insecurity Dilemma in South Korea, 1953-60" MACMILLAN PRESS LTD Houndmills, Basingstoke, Hampshire RG21 6XS and London.

[11] Tadjbakhsh, S. (2005). "Human Security: Concepts and Implications with an Application to Post-Intervention Challenges in Afghanistan”, Les Etudes du CERI, 117-118.

[12] Ostergard, R. L. (2002). "Politics in the hot zone: AIDS and national security in Africa", Third World Quarterly, 23 (2), 333-350.

[13] Floyd, R. (2007. "Human Security and the Copenhagen School's Securitization Approach: Conceptualizing Human Security as a Securitizing Move". Human Security Journal, 5 (winter), 38-49.

[14] Tadjbakhsh, S. (2009). "Human Security: Looking back before looking forward" The ICHSWA Conference Birjand, Iran November 26th 2009.

[15] Owen, T. (2004). "The Consolation of Security: Proposal for a Threshold-Based Definition”. Security Dialogue, 35 (3), 381-387. 
[16] DFAIT. (1999). "Human Security: Safety for People in a Changing World. Ottawa. Retrieved January 2, 2018, from http://summitamericas.org/Canada/HumanSecurityenglish.htm. P. 4.

[17] Salih, M. (2008). "Poverty and human security in Africa: the liberal peace debate" in Peace and Conflict in Africa", edited by David J. Francis, published in 2008 by Zed Books Ltd, pp, 171-185.

[18] ACLED Conflict trend report (July 2017: 3).

[19] Abbink J. 2011. "Ethnic-based federalism and ethnicity in Ethiopia: reassessing the experiment after 20 years", Journal of Eastern African Studies, 5:4, 596-618, DOI: 10.1080/17531055.2011.642516.

[20] Bach, J. N. (2011). Abyotawi Democracy: Neither Revolutionary nor Democratic," Critical Review of EPRDF's Design of Revolutionary Democracy in Post-1991 Ethiopia, " Journal of Eastern African Studies, Vol. 5, No. 4, 2011, p. 641-663.

[21] Merera G. 2011b. "Elections and democratization in Ethiopia, 1991-2010", Journal of Eastern African Studies, 5:4, 664-680.

[22] Markakis, J. (2011). "Ethiopia: The last two frontiers. Oxford, James Currey.

[23] Abbink, J. 2009. "The Ethiopian Second Republic and the Fragile "Social Contract", in Africa Spectrum, 44, 2, 3-28. ISSN: 1868-6869, p. 17.

[24] Vaughan, S. \& Tronvoll, K. 2003. "The Culture of Power in Contemporary Ethiopian Political Life", Edita Sverige: Stockholm. P. 132.

[25] Kassahun B. (2005). "Parliament and Dominant Party System in Ethiopia", In M. A. Mohamed Salih (Ed.), African Parliaments: between Governance and Government (pp. 162-181). Palgrave Macmillan.

[26] Merera, G. (2003). "The Elite and the Quest for Peace, Democracy, and Development in Ethiopia: Lessons to be Learnt", Northeast African Studies Vol. 10, No. 2 (New Series) 2003, pp. 141-164.
[27] Jan Záhořík (2017) Reconsidering Ethiopia's ethnic politics in the light of the Addis Ababa Master Plan and anti-governmental protests, The Journal of the Middle East and Africa, 8:3, 257-272, DOI: 10.1080/21520844.2017.1370330.

[28] Human Rights Watch (2017). "World report Ethiopia: events of 2016"https://www.hrw.org/world-report/2017/country chapters/ethiopia (Para, 3), accessed on 4/5/2018.

[29] Abbink, J. 2006. Discomfiture of Democracy: The 2005 Election Crisis in Ethiopia and its Aftermath. African Affairs 105 (2006): 173-99.

[30] Awol Allo. 2017. Protests, Terrorism, and Development: On Ethiopia's Perpetual State of Emergency. Yale Human Rights and Development Law Journal. Volume 19 | Issue 1 Article 4.

[31] International Crisis Group. 2009. "Ethiopia: Ethnic Federalism and its Discontents", Africa Report no. 153, September 4. Brussels.

[32] Haben, T. (2017). "State of Emergency: A Sign to Decayed Ethnic Federalism in Ethiopia" http://www.madote.com/2017/09/state-of-emergency-sign-todecayed.html Accessed on 5/19/2018.

[33] Melkamu, J. (2016). Land Grabbing and Violations of Human Rights in Ethiopia, Finfinnee tribune, accessed from $\mathrm{http}: / / w w w . a n y w a a s u r v i v a l . o r g / l a n d-g r a b b i n g-a n d-v i o l a t i o n s-$ of-human-rights-in-ethiopia/. January 28, On 2/7/2018.

[34] Urgessa (2016). “Analysis - Ethiopia's persistent food insecurity: What went wrong?" $\mathrm{http}: / /$ addisstandard.com/analysis-ethiopias-persistent-food-ins ecurity-what-went-wrong/. Accessed on 9/3/2017.

[35] Erwin, V. Veen. (2016). "Perpetuating power Ethiopia's political settlement and the organization of security", CRU Report, September 2016, Netherlands Institute of International Relations.

[36] Independent Advisory Group on Country Information. Country Policy and Information Note Ethiopia: Oromos. November 2019. 